\title{
Discussion Paper No. 13-049 \\ Revisiting the Link between Growth and Federalism: A Bayesian Model Averaging Approach
}

Zareh Asatryan and Lars P. Feld

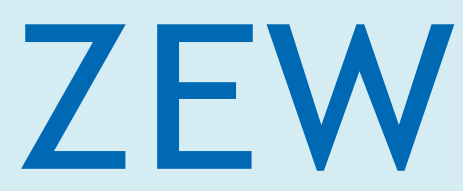

Zentrum für Europäische Wirtschaftsforschung $\mathrm{GmbH}$ Centre for European Economic Research 


\section{Discussion Paper No. 13-049 \\ Revisiting the Link between Growth and Federalism: A Bayesian Model Averaging Approach}

Zareh Asatryan and Lars P. Feld

Download this ZEW Discussion Paper from our ftp server:

http://ftp.zew.de/pub/zew-docs/dp/dp13049.pdf

Die Discussion Papers dienen einer möglichst schnellen Verbreitung von neueren Forschungsarbeiten des ZEW. Die Beiträge liegen in alleiniger Verantwortung der Autoren und stellen nicht notwendigerweise die Meinung des ZEW dar.

Discussion Papers are intended to make results of ZEW research promptly available to other economists in order to encourage discussion and suggestions for revisions. The authors are solely responsible for the contents which do not necessarily represent the opinion of the ZEW. 


\section{Non-technical Summary}

In the classic case fiscal federalism leads to economic growth by a more productive and possibly smaller public sector through higher preference homogeneity and enhanced intergovernmental competition. On the other hand, decentralized political decisions create inter-jurisdictional spillovers which may negatively affect growth by distorting local tax and fiscal incentives. In recent years, this discussion has led to a growing body of literature aimed at understanding the empirical link between the two phenomena. The results on the existence, direction or sign of such a link, however, are as ambiguous as ever.

The present paper takes a fresh look at the empirical relationship between fiscal federalism and output growth using a Bayesian model averaging approach. This approach is increasingly becoming a standard econometric tool in the empirical growth literature, because it offers a coherent procedure to deal with both model and parameter uncertainty in a context of weak theoretical guidance which has previously led researchers to choose their empirical specifications (explanatory variables and functional forms) on an arbitrary basis, or at best using some unknown rule-of-thumb rules. Surprisingly, however, the earlier literature on the link between growth and federalism - by definition being a part of this much larger literature on the determinants of economic growth and, thus, sharing the same methodological limitations - has never adopted these advancements.

Obviously, endogeneity and causality are the main concerns of these studies, but the methodological superiority of the present analysis allows for claiming that the results of previous research might have been additionally biased due to over restrictive model specification. In contrast, the results from a sample of 23 OECD countries over 1975-2000 indicate that after controlling for unobserved country heterogeneity, there is no robust link, neither positive, nor negative, between output growth and fiscal federalism. 


\section{Das Wichtigste in Kürze}

Die ökonomische Theorie des Föderalismus geht davon aus, dass fiskalischer Föderalismus im klassischen Fall - aufgrund eines dank höherer Präferenzhomogenität und erweitertem intergouvernementalen Wettbewerb produktiveren und möglicherweise kleineren öffentlichen Sektor - zu höherem Wirtschaftswachstum führt. Jedoch verursachen dezentralisierte politische Entscheidungen Spillover-Effekte über Gebietskörperschaften hinweg, die das Wachstum durch verzerrende Kommunalsteuern und Fiskalanreize beeinträchtigen können. In den letzten Jahren hat diese Diskussion mit dem Anliegen, den empirischen Zusammenhang zwischen den beiden Phänomenen zu verstehen, zu einer wachsenden Literatur geführt. Allerdings sind die Ergebnisse über Existenz, Richtung und Vorzeichen eines solchen Zusammenhangs widersprüchlich.

Die vorliegende Studie verwendet ein Bayesianischen Modell (Bayesian model averaging) und wirft damit einen neuen Blick auf den empirischen Zusammenhang zwischen fiskalischem Föderalismus und Wirtschaftswachstum. Dieses Verfahren wird zunehmend zum ökonometrischen Standard in der empirischen Wachstumsliteratur, denn es bietet ein kohärentes Vorgehen im Umgang mit Modell- und Parameterunsicherheit im Kontext schwacher Orientierung durch die Theorie. Dies hat Forscher zuvor dazu veranlasst empirische Spezifikationen der erklärenden Variablen und des funktionalen Zusammenhangs auf beliebiger Grundlage oder allenfalls unter Verwendung bloßer Daumenregeln vorzunehmen. Überaschenderweise wurden diese Verbesserungen in früheren Studien über den Zusammenhang zwischen Wachstum und Föderalismus - die per Definition einen Teil der umfangreicheren Literatur über die Determinanten wirtschaftlichen Wachstums sind und daher denselben methodologischen Einschränkungen unterliegen - nicht aufgegriffen.

Die Hauptsorgen dieser Studien gelten ganz offensichtlich der Endogenität und Kausalität, doch kann aufgrund der methodologischen Vorzüge der vorliegenden Studie gesagt werden, dass die Ergebnisse der bisherigen Forschung durch zu restriktive Modellspezi- 
fikationen zusätzlich verzerrt wurden. Demgegenüber weisen die Ergebnisse eines Datensatzes, der 23 OECD-Länder im Zeitraum von 1975-2000 umfasst, darauf hin, dass es unter Kontrolle nicht beobachtbarer Länderheterogenität keinen stabilen, weder einen positiven noch einen negativen, Zusammenhang zwischen Wirtschaftswachstum und fiskalischem Föderalismus gibt. 


\title{
Revisiting the Link between Growth and Federalism:
}

\section{A Bayesian Model Averaging Approach}

\author{
Zareh Asatryan* \\ (ZEW Mannheim and University of Freiburg) \\ Lars P. Feld \\ (Walter Eucken Institute and University of Freiburg)
}

July, 2013

\begin{abstract}
Following the ambiguous results in the literature aimed at understanding the empirical link between fiscal federalism and economic growth, this paper revisits the question using a Bayesian Model Averaging approach. The analysis suggests that the failure to appropriately account for model uncertainty may have previously led to biased estimates. The results from a sample of 23 OECD countries over 1975-2000 indicate that after controlling for unobserved country heterogeneity, there is no robust link, neither positive, nor negative, between output growth and fiscal federalism (measured as sub-national governments' share of own source tax revenue).
\end{abstract}

Keywords: Fiscal Federalism, Economic Growth, Bayesian Model Averaging JEL codes: C11, H70, O43

${ }^{*}$ Corresponding author: Zareh Asatryan, ZEW, L7 1, 68161 Mannheim, Germany; Tel.: $(+49) 6211235392$; Email: asatryan@zew.de

We gratefully acknowledge Martin Feldkirchner, Friedrich Heinemann, Franz Hubert, Branimir Jovanovic, Armine Khachatryan, Enrique Moral-Benito, Ulrich Thießen, Bengt-Arne Wickström and seminar participants at American Public Choice Society, Armenian Economic Association, Centre for European Economic Research, Humboldt University of Berlin, International Institute of Public Finance and Social Science Research Center Berlin for valuable comments.

This paper is a revised version of Zareh Asatryan's master thesis written at HU Berlin titled "Fiscal Decentralization and Economic Growth in OECD Countries: A Bayesian Model Averaging Approach". 


\section{Introduction}

A couple of decades ago decentralization used to be a matter of marginal importance for public economics scholars and for policy makers. Countries were constitutionally divided into federal or unitary systems and there were hardly any political or economic initiatives for restructuring. This was the post-World War II period, characterized by rapid growth in public spending. The resulting large government involvement in the economy eventually raised concerns over public sector performance and over its further potential in sustaining permanent economic growth rates. This brought the issue of optimal allocation of fiscal authority between different government layers to prominence in the academic and policy debates. Fiscal federalism of course remains a complex multidimensional phenomenon, but an important trade-off that has attracted much academic attention is whether the growth-stimulating benefits from making decisions at appropriate levels are outweighed by the costs of duplicating government efforts.

In the classic case fiscal federalism leads to growth by a more productive and possibly smaller public sector through higher preference homogeneity (Oates, 1972) and enhanced inter-jurisdictional competition (Tiebout, 1956, Brennan and Buchanan, 1980). On the other hand decentralized political decisions create inter-jurisdictional spillovers (Musgrave, 1959, Oates, 1972) which negatively affect growth by distorting local tax and fiscal incentives. Less conventional arguments that could go in both directions range from economies of scale (Prud'homme, 1995, Rodriguez-Pose and Ezcurra, 2010) and macroeconomic stability (Ter-Minassian, 1997, Fukasaku and de Mello, 1999, Martinez-Vazquez and McNab, 2006) to government accountability (Martinez-Vazquez and McNab, 2003) and institutional quality (Ahmad and Tanzi, 2002).

The results of the growing empirical literature on the link between fiscal federalism and economic growth are at least as diverse $1^{1}$ The reason behind such inconclusiveness is that the impact of decentralization on growth has hardly been analyzed in a systematic man-

\footnotetext{
${ }^{1}$ See Feld et al. (2009) for a detailed overview followed by a literature meta-analysis, and Feld and Schnellenbach (2011) for a summary.
} 
ner (Feld et al., 2009). These papers typically analyze different cross-country samples with various measures of fiscal federalism and with diverse, often restrictive, methodologies. Davoodi and Zou (1998), Rodriguez-Pose and Ezcurra (2010), Bodman (2011), Baskaran and Feld (2013) are among those authors who provide evidence for a negative relation between federalism and growth, while Yilmaz (2000), Iimi (2005) report opposite results. Woller and Phillips (1998), Thornton (2007) do not find such a robust direct link. Thiessen (2003) tries to link these results together by arguing that the relation is inverse-U shaped, while Enikolopov and Zhuravskaya (2007) maintain that fiscal federalism can potentially enhance growth, but only conditional on good institutions. Case studies on federal countries such as Australia (Bodman et al., 2009) China (Zhang and fu Zou, 1998), India (Zhang and fu Zou, 2001), Russia (Desai et al., 2005), Switzerland (Feld et al., 2005) or the United States (Xie et al., 1999, Akai and Sakata, 2002, Stansel, 2005, Hatfield and Kosec, 2013) again lead to ambiguous results.

According to Breuss and Eller (2004), the uncertain results of empirical papers may be interpreted as the theoretical trade-off construction that reflects the various gains and drawbacks of fiscal federalism. We take a different position here. The empirical estimations have crucial limitations and are not very reliable. In particular, what is surprising is that the empirical literature on fiscal federalism and growth, by definition being a part of the much larger literature on the determinants of economic growth (one of the most prominent early contributions being Barro (1991)), did not sufficiently follow recent innovations of this larger field. Hence, our aim is to contribute to the understanding of the empirical link between fiscal federalism and economic growth by adopting the methodological refinements of growth empiricism.

With the recent exceptions of Brueckner (1999), Brueckner (2006), Rauscher (2007), Köthenbürger and Lockwood (2010) and Hatfield (2012) theoretical foundations of the impact of fiscal federalism on economic growth have remained scarce and have, therefore, limited the legitimacy of previous empirical work. This relative absence of guidance

\footnotetext{
${ }^{2}$ Similar to us, Bodman et al. (2009) applies a BMA approach, however using time-series data.
} 
from economic theory on channels through which fiscal federalism should affect growth left most researchers to choose their empirical specifications (explanatory variables and functional forms) on an arbitrary basis, or at best using some unknown rule-of-thumb rules. The vast amount of literature on the determinants of economic growth, on the other hand, has identified over 150 (Durlauf et al., 2005) or more variables to have explanatory power and has accordingly developed new methodological approaches of analyzing such high amounts of regressors. Ironically, federalism - either fiscal, political, administrative or of any other dimension - has never had its place among these determinants of economic growth.

In particular, we closely follow the works of Sala-i Martin (1997), Fernandez et al. (2001), Sala-i Martin et al. (2004) and others to extend the discussion by applying a Bayesian Model Averaging (BMA) approach which provides a coherent procedure to account for both model and parameter uncertainty. BMA also considers a very large set of models by allowing any subset of up to our 25 hypothetical growth determinants to enter the regressions (this totals to $2^{25}$ or over 33 million different models to deal with). Our estimates are based on a sample of 23 OECD countries over the 1975-2000 period, where fiscal federalism is measured as the share of tax revenues, over which sub-national governments have the autonomy to fully or partly decide upon tax rates or bases. The initial cross-country estimates on the determinants of per capita growth find a moderately negative coefficient for the above measure of fiscal federalism (and for the federation dummy), but weakly positive coefficients for dummies capturing the existence of locally elected sub-national parliaments/governments. These results are, however, not robust to the inclusion of country (and time) fixed effects into the BMA model, suggesting that the results of previous research might be biased due to over restrictive model specification.

The remainder of this paper is organized as follows. In the next section we describe the data and the analytical framework. Section 3 presents the empirical findings. The last section 4 concludes and offers several directions for future research. 


\section{Data and Methodology}

The first challenge of our empirical estimation is to find an accurate measure of the prevailing degree of fiscal federalism. Many of the previous empirical studies use IMF's Government Finance Statistics (GFS) to quantify fiscal federalism by computing the ratio of regional-to-total government expenditure and revenue (ExpDCT and RevDCT). Despite its merits and popularity, however, concerns are rising over these widely used measures of fiscal federalism, as they severely overestimate the sub-national fiscal independence by failing to make an appropriate distinction between sub-national government's real fiscal autonomy and its administrative activities tightly regulated by the center. We attempt to tackle these issues by adopting a dataset constructed by Stegarescu (2005), which supposedly captures the true amount of sub-national fiscal autonomy by differentiating tax revenue according to the degree of autonomy that the sub-national governments possess over the associated tax rates and tax bases.

Figure 1 plots the traditional GFS measures of fiscal federalism (ExpDCT and RevDCT) against the two Stegarescu (2005) measures, defined as revenue autonomy of first degree - RAut1 - measured as the share of tax revenue over which the sub-national government has the full autonomy to set the tax rate or base, and a softer revenue autonomy of second degree - RAut2 - which additionally considers shared tax revenues over which the central and sub-national authorities jointly co-decide the revenue splitting mechanism. The Stegarescu (2005) data has clear advantages which, for example, can be observed by comparing two neighboring, albeit very different, federations of Germany and Switzerland. Whereas GFS measures rank them in about the same position in their degrees of fiscal decentralization, Stegarescu (2005)'s measures allow distinguishing between the two types of federalisms that have become to be known as cooperative and competitive, respectively. The former is characterized by wide spending responsibilities at the sub-national level, which, however, are non-discretionary and are financed by a system of extensive equalization payments. On the contrary, sub-national governments in the 
Figure 1: Four cross-country measures of Fiscal Federalism, averaged over 1995-2001

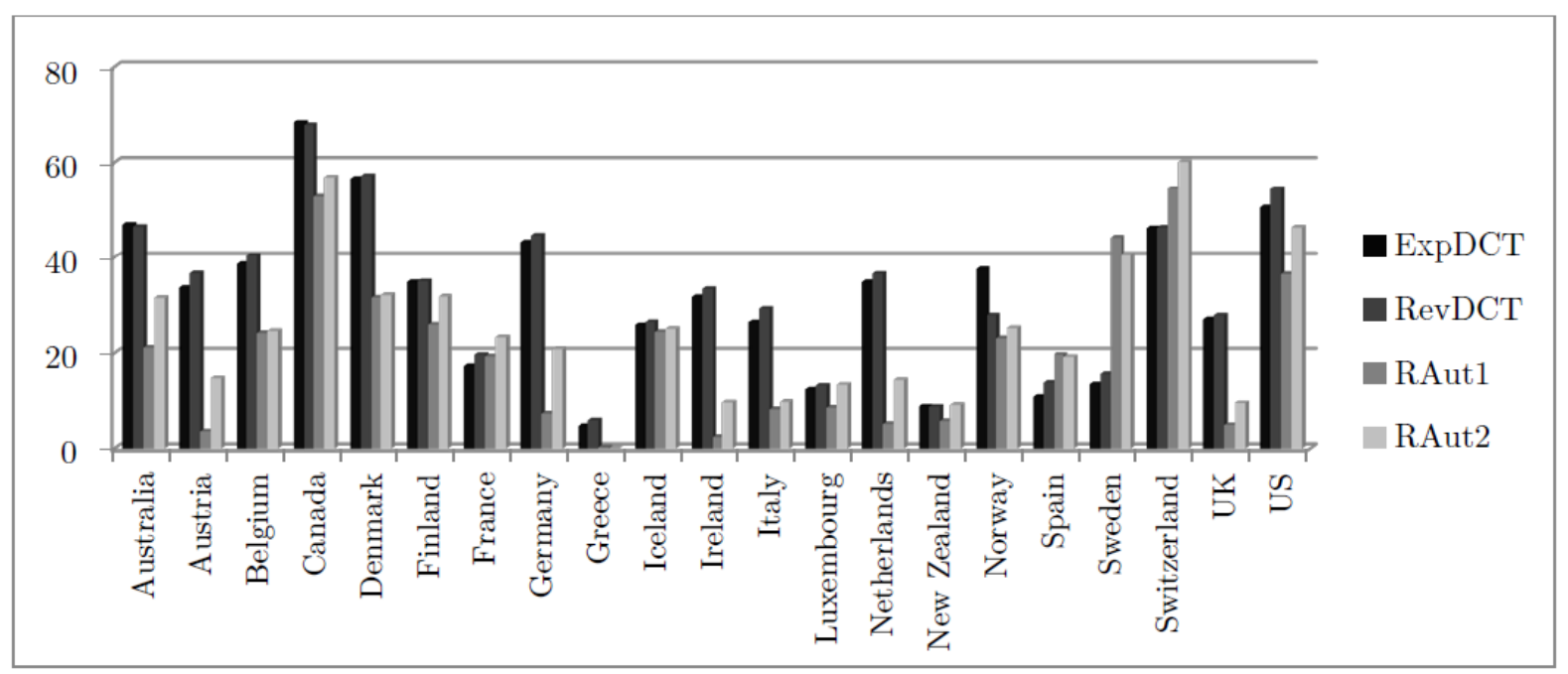

Notes: Own calculations based on data from IMF-GFS and Stegarescu 2005).

latter case have one of the highest autonomies in our sample (and in the world) over their spending and taxing decisions, and are thus competing with each other ${ }^{3}$

Figure 2 presents the evolution of fiscal federalism measured by RAut1 for selected economies. Note that relative to the competing measures of federalism (including the GFS measures, but also dummies capturing political/administrative features of federalism such as countries proclaimed as federalist by constitution, existence of autonomous regions, presence of locally elected governments and parliaments etc), considerable crosstime variance is observed in case of $R A u t 1$ and $R A$ ut2. Some illustrious examples include the governments of France, Italy and Spain which significantly shifted their fiscal power towards lower governmental layers, or Belgium which following a process of reforms became a federal state in 1993 (Belgium has experienced the highest average increase in sub-national fiscal autonomy in the sample, that equals about 0.8 percentage points per year). On the opposite, Norway, Switzerland and the UK became more centralized on average. Still, the majority of countries in the sample did not see significant changes over time. This includes constitutionally decreed federal countries (which could have been a

\footnotetext{
${ }^{3}$ By construction, Stegarescu (2005)'s both measures of revenue autonomy should always be below the GFS's measure of RevDCT, which, however, does not hold for the entire sample indicating that the two datasets are not consistent with each other and, thus, should be treated with care when used jointly.
} 
Figure 2: Evolution of sub-national government revenue autonomy - RAut1 - over 19752000 for selected OECD economies

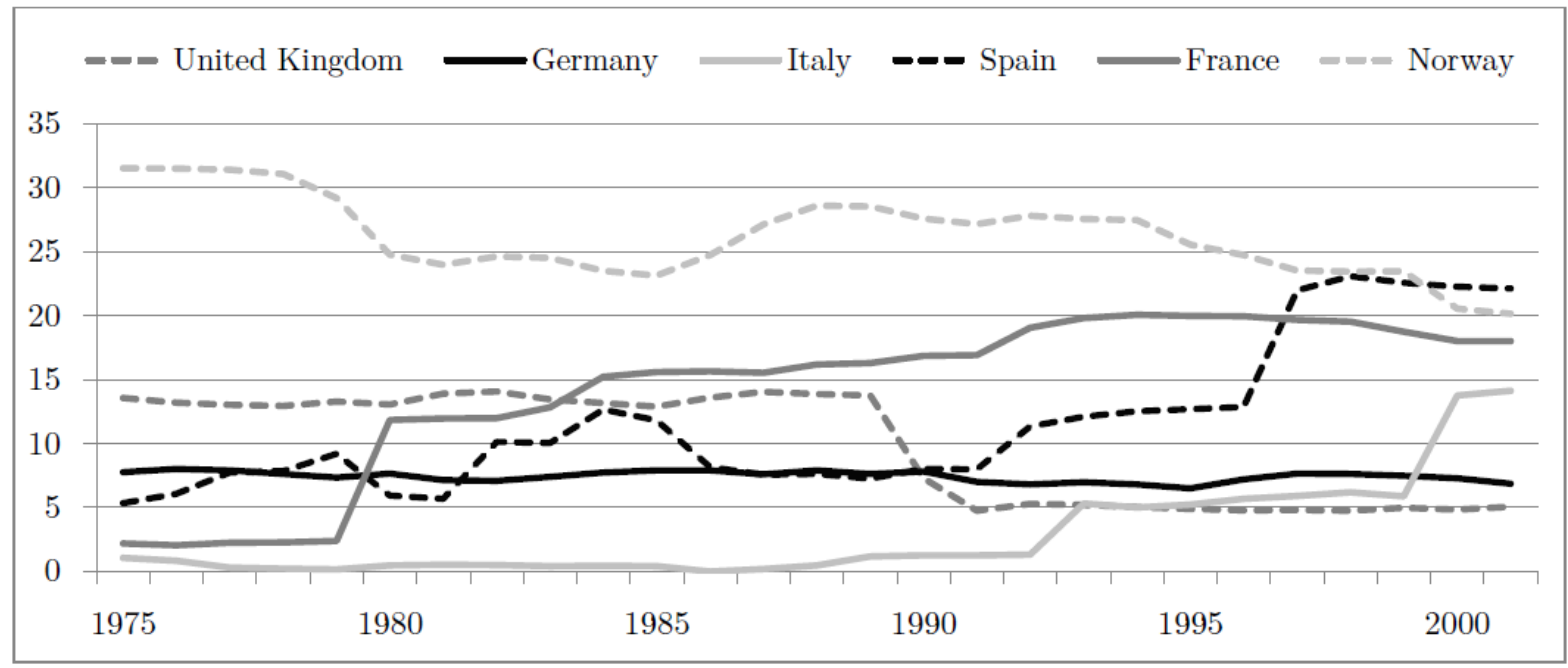

Notes: Own calculations based on data from Stegarescu (2005).

source of important variation) such as Germany that stagnated at a low $7 \%$ average level, or the US with $37 \%$ of local revenue coming from own sources.

The two measures of fiscal federalism, $R A u t 1$ and $R A u t 2$, are our main variables of interest which will be regressed on PPP-adjusted per capita GDP growth rates. The sample is restricted to 23 OECD countries (listed in Figure 1 and additionally including Japan and Portugal) where these more reliable measures of federalism are available. The remaining explanatory variables are borrowed from the large literature on cross-country growth empirics, which over the last two decades has proposed a long list of variables as growth determinants. In particular, in addition to the two measures of revenue autonomy, we include 16 panel variables to capture various macro-economic, political, social and demographic phenomena and 8 further cross-country variables to account for differences in initial conditions and in geography. Overall we construct a database of 27 variables for 23 OECD countries from 1975 to 2000: Table 1 presents the summary statistics, sources and short descriptions of the employed variables.

To formally address the specification uncertainty of analyzing this amount of variables, we follow the recent advancements in the empirical growth literature and apply 
an already rather standard BMA approach (see for example Levine and Renelt (1992), Sala-i Martin (1997), Fernandez et al. (2001), Sala-i Martin et al. (2004), Masanjala and Papageorgior (2008), Moral-Benito (2012), and Raftery (1995) or Durlauf et al. (2005) for a discussion on BMA or broader variety of econometric methods employed to study growth). In particular, we consider a set of linear equations where the GDP growth rate per country-year is regressed on a constant term and on any subset of up to the 25 hypothetical growth determinants (including measures of fiscal federalism) specified above. Briefly, the idea is to a priori declare that the "true" model is unknown, which implies a departure from the classical methodology in which conditioning on a specified model is essential. Consequently, instead of traditional conditioning, the employed Bayesian inference attaches prior non-informative beliefs to the model parameters (i.e. coefficients and error variance). In the next - averaging - step, the (unconditional) estimator is computed as a weighted average of these conditional estimators. A formal and more detailed specification of the approach we apply is presented by Magnus et al. (2010).

We add to the above by extending the analysis to a panel dataset. This allows including country fixed effects to tackle the issue of unobserved cross-country heterogeneity. The trade-off, however, is that we are risking to limit our available information to the inadequately low within-country variation of the fiscal federalism variables $4^{4}$ Indeed, it is not uncommon to argue that the underlying features of federalism are mainly constitutional and, so, do not vary much over time. Thus, in the next section we present estimations using both pooled data to exploit the cross-country constitutional differences and data demeaned by country (and year) averages to control for unobserved country characteristics 5

\footnotetext{
${ }^{4}$ Baskaran and Feld (2013) present evidence on the within variance of these measures which are then exploited by applying country fixed effects models.

5 Lovell (2008) shows that this approach of demeaning data is equivalent to using fixed effects (we are constrained of using fixed effects dummies as the inclusion of further variables into the model makes the analysis computationally prohibitive).
} 


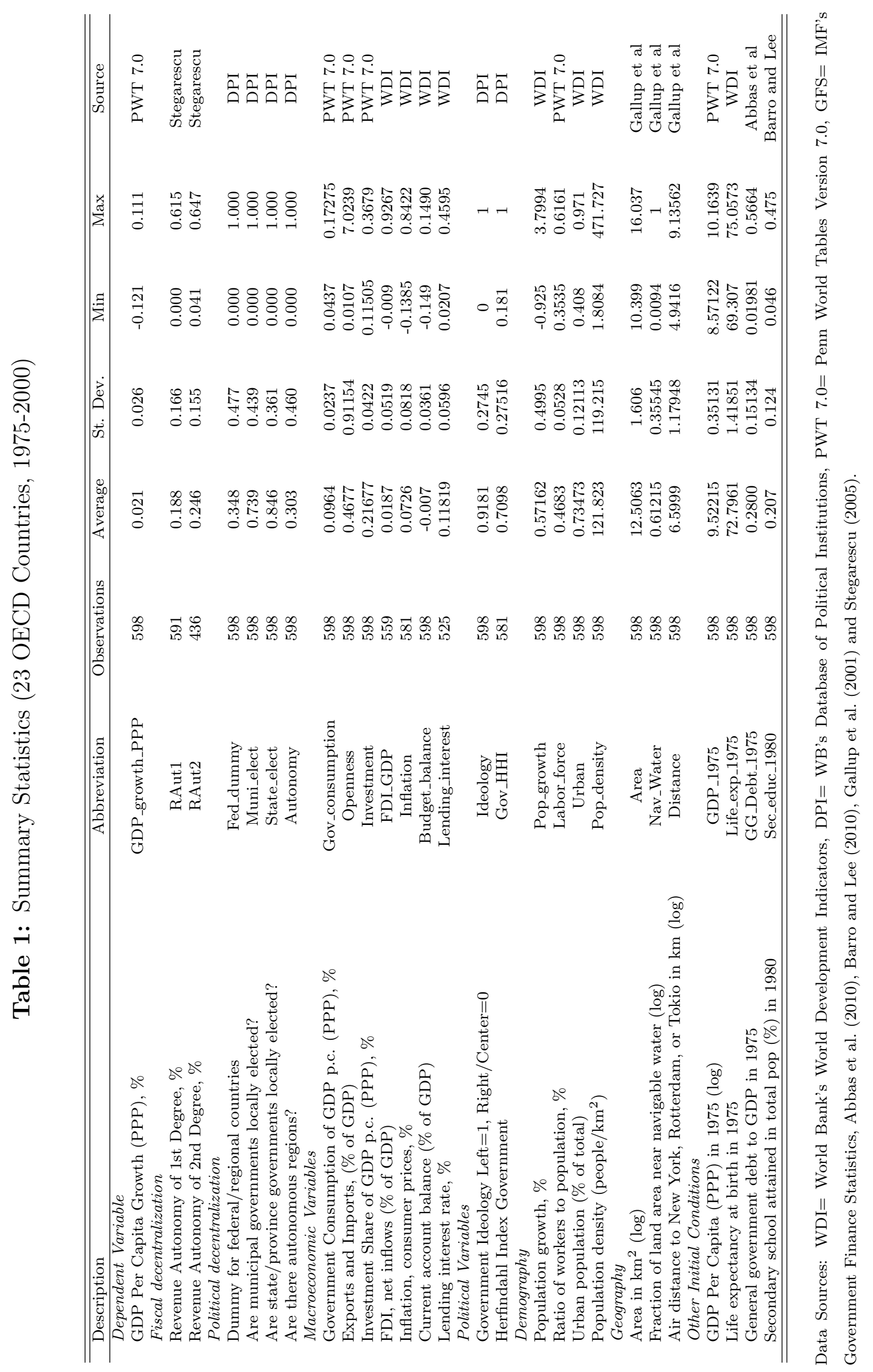




\section{Results}

Table 2 presents the BMA estimation results with PPP-adjusted per capita GDP growth rate as the dependent variable. Model (1) is the baseline specification with pooled data, and model (2) extends the set of explanatory variables by including cross-country controls for initial conditions and for geographic differences. Model (3) is a variant of the latter specification but controlling for common time shocks, while models (4) to (6) our most reliable specifications - additionally account for unobserved country heterogeneity. In models (1) to (4) the fiscal federalism measure entering the regression is the sub-national governments' revenue autonomy of first degree (RAut1), model (5) uses the softer measure of revenue autonomy of second degree (RAut2), while model (6) tests for a non-linear relation between growth and federalism. The last two models (7) and (8) serve as robustness by estimating the time fixed effects model (3) on 5-year averages data and on annual data excluding the case of Switzerland, respectively.

The first column of each model reports the estimated coefficient, i.e. the weighted posterior means of the regressors' coefficients and since it is not straightforward to interpret coefficient estimates that are averaged over many models of different size and form, we will be mainly interested in their sign (rather than their value). The second columns report the posterior inclusion probability that is the posterior probability that a variable is included in the model. As a guideline to compare to frequentist hypothesis testing, Raftery (1995) and Masanjala and Papageorgior (2008) suggest that a posterior probability of $50 \%$ roughly corresponds to a t-ratio of one in absolute terms. Although the BMA literature has not reached a consensus regarding a threshold value on the "significance" of posterior probabilities, such question does not rise in our estimation as a fair number of growth determinants clearly appear in the top rows of Table 2 with above 90\% probabilities, while the inclusion probabilities of the rest are discontinuously low.

Among these variables the following are positively linked to output growth rates across models: the share of investment expenditure in GDP - Investment - as one of the central 
growth generating economic factors; the share of the sum of exports and imports in GDP - Openness - that reflect the economic benefits of exploiting comparative advantages of foreign trade and other gains of economic integration; the budget surplus to GDP ratio Budget_balance - indicating the presence of pro-cyclical central government fiscal policies; and a measure of territorial size - Log_Area - showing scale effects. Unlike the latter, the remainder of time-invariant variables such as the controls of initial conditions do not have high posterior inclusion probabilities, perhaps because of the relative homogeneity of countries in the sample in terms of their income levels. Two monetary variables Inflation and Lending_interest enter the regressions with the expected negative signs. The standard arguments for lower and more stable inflation rates is the reduced economic uncertainty and improved efficiency of the price mechanism, while the rate of lending interest rate is an indicator of healthy financial systems assuming that accessibility to cheap money positively affects capital accumulation and, thus, contributes to economic growth. Finally, the share of government consumption in GDP also has a high posterior inclusion probability, interestingly, indicating a reverse relation to economic growth.

Turning to the central variables of interest, initial cross-country estimates (models 1-2) find a significantly negative coefficient for the fiscal autonomy indicator - RAut1 - and for the time-invariant federation dummy - Fed_Dummy - but weakly positive coefficients for dummies capturing the existence of locally elected sub-national parliaments or governments. These results are maintained when controlling for common time shocks (model 3), however they are not robust to the inclusion of country fixed effects (models 4-6). Likewise, no such evidence is found for the softer measure of local fiscal autonomy $R A$ ut2 (model 5) or for a quadratic relation (model 6) as some scholars suggest.

As discussed earlier, by including country fixed effects we are potentially running into the risk of limiting the available information on fiscal federalism to within-country variance that might be too low. A loss of significance could then just mean inadequate empirical specification rather than absence of such a link. Contrary to this argument, however, in models (7) and (8) we show that the results of a negative growth-federalism 
relation are too sensitive to be considered robust. First, the results do not hold in a 5-year averages replication of the time fixed effects model, suggesting that they might have been driven by short-term business cycle fluctuations. Moreover, the significance of the sub-national fiscal autonomy variable, as well as of the constitutional fiscal federalism dummy, almost entirely vanish when we exclude one of the most interesting cases of federalism - Switzerland - from the sample, which unlike most of the countries in the sample, has experienced a high within variation in RAut1 during the period considered (it had the second lowest level of average annual growth in sub-national fiscal autonomy of about -0.4 percentage points). But given the high possibility of failure in properly accounting for Switzerland's unique institutions (even with such an extensive set of controls, but no country fixed effects), generalization of these results to the whole sample might well be biased.

Contrary to the findings of many previous empirical studies, which claim significantly negative or positive relations between growth and fiscal federalism, our analysis suggests that there is no such robust link. Obviously, endogeneity and causality are the main concerns of these studies, but the methodological superiority of our analysis allows us to claim that the results of previous research might have been additionally biased due to over restrictive model specification. As the contrast between models (1) to (3) on one side, and models (4) to (6), model (7) and model (8) of Table 2 on the other shows one particular source of such bias may well be the failure to properly account for cross-country unobserved heterogeneity. 


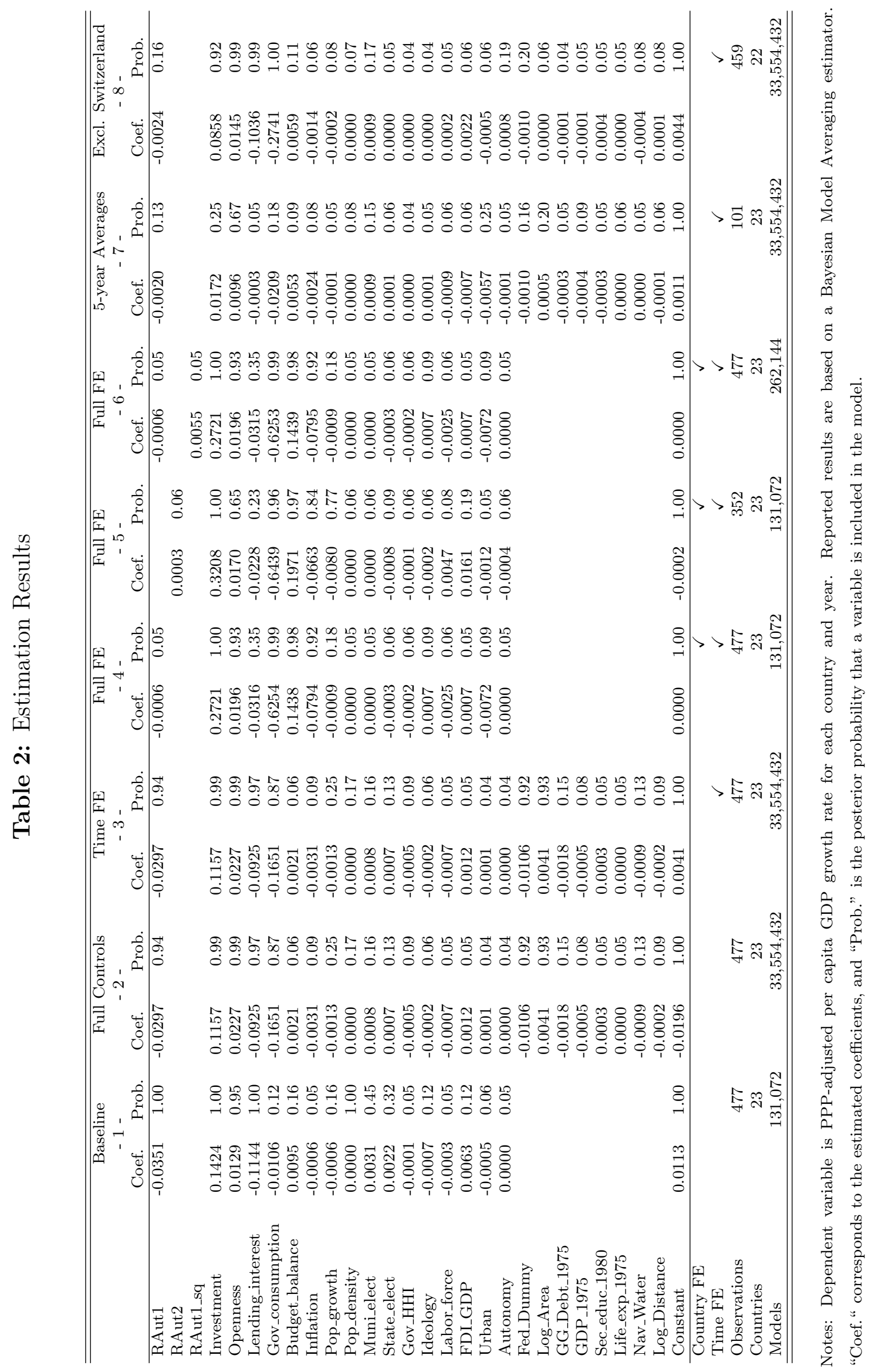




\section{Conclusion}

In the present paper we take a fresh look at the empirical relationship between fiscal federalism and economic growth using a Bayesian model averaging (BMA) approach. BMA is increasingly becoming a standard econometric tool in the empirical growth literature, because it offers a coherent procedure to deal with both model and parameter uncertainty in a context of weak theoretical guidance. Surprisingly, however, the earlier literature on the link between growth and federalism - by definition being closely linked to the empirical growth literature and, thus, sharing the same methodological shortcomings - has never adopted these advancements. We aim at covering this gap and show that previous research which claims to have found a significant, either negative or positive, relation between growth and fiscal federalism is biased due to over restrictive model specification. In contrast, our estimations indicate that after controlling for unobserved country heterogeneity there is no such direct link.

One particular issue that has largely burdened the legitimacy of the literature on the link between fiscal federalism and economic performance is the tendency of oversimplifying the relation between the two highly multi-dimensional phenomena by comparing their aggregated values. As our results underline the importance of country heterogeneity, we believe that future empirical research should consider the channels through which different aspects of federalism influence different facets of the economy in different institutional settings by paying particular attention to the relevant mechanisms in detail. Other well known issues such as endogeneity and causality that are common to the growth literature in general, will of course remain important.

From a policy perspective, the absence of such a direct link implies that at least there is no trade-off between federalism and growth. This suggests that a careful institutional design may still allow the realization of many benefits of federalism that originate from, for example, increased preference homogeneity or through enhanced inter-jurisdictional competition. 


\section{References}

Abbas, A., N. Belhocine, A. El-Ganainy, and M. Horton (2010). A historical public debt database. Working Paper 10/245, IMF.

Ahmad, E. and V. Tanzi (2002). Managing Fiscal Decentralization. New York: Routledge.

Akai, N. and M. Sakata (2002). Fiscal decentralization contributes to economic growth: evidence from state-level cross-section data for the United States. Journal of Urban Economics 52(1), 93-108.

Barro, R. J. (1991). Economic growth in a cross section of countries. Quarterly Journal of Economics 106(2), 407-443.

Barro, R. J. and J.-W. Lee (2010). A new data set of educational attainment in the world, 1950-2010. Working Paper 15902, NBER.

Baskaran, T. and L. P. Feld (2013). Fiscal decentralization and economic growth in OECD countries is there a relationship? Public Finance Review 41(4), 421-445.

Bodman, P. (2011). Fiscal decentralization and economic growth in the OECD. Applied Economics 43(23), 3021-3035.

Bodman, P., K.-A. Heaton, and A. Hodge (2009). Fiscal decentralisation and economic growth: A Bayesian model averaging approach. Working Paper 3509, University of Queensland.

Brennan, G. and J. Buchanan (1980). The power to tax: analytical foundations of a fiscal constitution. Cambridge University Press.

Breuss, F. and M. Eller (2004). Fiscal decentralization and economic growth: Is there really a link? Journal for Institutional Comparisons 2(1), 3-9.

Brueckner, J. K. (1999). Fiscal federalism and capital accumulation. Journal of Public Economic Theory 1(2), 205-224. 
Brueckner, J. K. (2006). Fiscal federalism and economic growth. Journal of Public Economics 90(10), 2107-2120.

Davoodi, H. and H. Zou (1998). Fiscal decentralization and economic growth: A crosscountry study. Journal of Urban Economicsy 43(2), 244-257.

Desai, R. M., L. Freinkman, and I. Goldberg (2005). Fiscal federalism in rentier regions: evidence from Russia. Journal of Comparative Economics 33(4), 814-834.

Durlauf, N. S., P. A. Johnson, and J. R. Temple (2005). Growth econometrics. In P. Aghion and S. N. Durlauf (Eds.), Handbook of economic growth, Volume 1A, pp. 555-677. Amsterdam, North-Holland.

Enikolopov, R. and E. Zhuravskaya (2007). Decentralization and political institutions. Journal of public economics 91 (11), 2261-2290.

Feld, L. P., T. Baskaran, and J. Schnellenbach (2009). Fiscal federalism, decentralization and economic growth: A meta-analysis. Working paper, University of Heidelberg.

Feld, L. P. and J. Schnellenbach (2011). Fiscal federalism and long-run macroeconomic performance: a survey of recent research. Environment and Planning C: Government and Policy 29(2), 224-243.

Feld, P. L., G. Kirchgässner, and C. A. Schaltegger (2005). Fiskalischer Föderalismus und wirtschaftliche Entwicklung: Evidenz für die Schweizer Kantone. Jahrbuch für Regionalwissenschaft/Review of Regional Research 25, 3-25.

Fernandez, C., E. Ley, and M. Steel (2001). Model uncertainty in cross-country growth regressions. Journal of Applied Econometrics 16(5), 563-576.

Fukasaku, K. and L. de Mello (1999). Fiscal decentralisation in emerging economies: governance issues. Paris: OECD Publishing.

Gallup, J., A. Mellinger, and J. Sachs (2001). Geography datasets. Dataset, Center for International Development at Harvard University. 
Hatfield, J. W. (2012). Federalism, taxation, and economic growth. Working paper, Stanford University.

Hatfield, J. W. and K. Kosec (2013). Federal competition and economic growth. Journal of Public Economics 93(1), 144-159.

Iimi, O. (2005). Decentralization and economic growth revisited: An empirical note. Journal of Urban Economics 57(3), 449-461.

Köthenbürger, M. and B. Lockwood (2010). Does tax competition really promote growth? Journal of Economic Dynamics and Control 34(2), 191-206.

Levine, R. and R. Renelt (1992). A sensitivity analysis of cross-country growth regressions. American Economic Review 82(5), 942-963.

Lovell, M. (2008). A simple proof of the Frisch-Waugh-Lovell theorem. Journal of Economic Education 39(1), 88-91.

Magnus, J. R., O. Powell, and P. Prüfer (2010). A comparison of two model averaging techniques with an application to growth empirics. Journal of Econometrics 154(2), $139-153$.

Martinez-Vazquez, J. and R. M. McNab (2003). Fiscal decentralization and economic growth. World development 31(9), 1597-1616.

Martinez-Vazquez, J. and R. M. McNab (2006). Fiscal decentralization, macrostability and growth. Hacienda publica espanola 179, 25-50.

Masanjala, W. H. and C. Papageorgior (2008). Rough and lonely road to prosperity: a reexamination of the sources of growth in Africa using Bayesian model averaging. Journal of Applied Econometrics 23(5), 671-682.

Moral-Benito, E. (2012). Determinants of economic growth: a Bayesian panel data approach. Review of Economics and Statistics 94(2), 566-579. 
Musgrave, R. (1959). The Theory of Public Finance. New York: McGraw-Hill.

Oates, W. E. (1972). Fiscal Federalism. London: Harcourt Brace.

Prud'homme, R. (1995). The dangers of decentralization. World Bank Research Observer $10(2), 201-220$.

Raftery, A. (1995). Bayesian model selection in social research. Sociological Methodology 25, 111-163.

Rauscher, M. (2007). Tax competition, capital mobility and innovation in the public sector. German Economic Review 8(1), 28-40.

Rodriguez-Pose, A. and R. Ezcurra (2010). Is fiscal decentralization harmful for economic growth? evidence from the OECD countries. Journal of Economic Geography 10(3), $3-34$.

Sala-i Martin, X. (1997). I just ran two million regressions. American Economic Review $87(2), 178-183$.

Sala-i Martin, X., G. Doppelhofer, and R. Millerl (2004). Determinants of long-term growth: A Bayesian averaging of classical estimates (bace) approach. American Economic Review 94(4), 813-835.

Stansel, D. (2005). Local decentralization and local economic growth: A cross-sectional examination of US metropolitan areas. Journal of Urban Economics 57(1), 55-72.

Stegarescu, D. (2005). Public sector decentralization: Measurement concepts and recent international trends. Fiscal Studies 26(3), 301-333.

Ter-Minassian, T. (1997). Decentralization and macroeconomic management. Working Paper 97/155, IMF.

Thiessen, U. (2003). Fiscal decentralization and economic growth in high income OECD countries. Fiscal Studies 24(3), 237-274. 
Thornton, J. (2007). Fiscal decentralization and economic growth reconsidered. Applied Economics 61(1), 64-70.

Tiebout, C. (1956). A pure theory of local expenditures. Journal of Political Economy $64(5), 416-424$.

Woller, G. and K. Phillips (1998). Fiscal decentralization and LDC economic growth: An empirical investigation. Journal of Development Studies 34(4), 139-148.

Xie, D., H. fu Zou, and H. Davoodi (1999). Fiscal decentralization and economic growth in the United States. Journal of Urban Economics 45(2), 228-239.

Yilmaz, S. (2000). The impact of fiscal decentralization on macroeconomic performance. National Tax Association, Proceedings of the 92nd Annual Conference on Taxation, $251-260$.

Zhang, T. and H. fu Zou (1998). Fiscal decentralization, public spending, and economic growth in china. Journal of Public Economics 67(2), 221-240.

Zhang, T. and H. fu Zou (2001). The growth impact of intersectoral and intergovernmental allocation of public expenditure: With applications to China and India. China Economic Review 12(1), 58-81. 